\title{
PENINGKATAN PRESTASI BELAJAR PKN MENGGUNAKAN MODEL KOOPERATIF STUDENT TEAM ACHIEMENT DIVISION (STAD)
}

\author{
I Nyoman Suwendra \\ Email: inyomansuwendra2018@gmail.com
}

\begin{abstract}
ABSTRAK
Penelitian tindakan kelas yang dilaksanakan ini memiliki tujuan untuk meningkatkan prestasi belajar peserta didik. Perolehan data awal yang rendah pada siswa kelas IVB Semester I SD No. 4 Sibanggede Tahun Pelajaran 2015/2016 membuat peneliti mengupayakan membenahi proses yang kurang baik yang telah dilaksanakan. Perbaikan proses pembelajaran dilakukan melalui penerapan model pembelajaran Kooperatif Student Team Achiement Division (STAD). Model ini diharapkan dapat memecahkan permasalahan yang sedang dihadapi. Setelah data dikumpulkan melalui instrumen tes prestasi belajar, diperoleh peningkatan hasil belajar dengan data awal yang rata-rata kelasnya yaitu mencapai 72,57dengan prosentase ketuntasan belajar baru mencapai 33,33\%, pada siklus I meningkat menjadi 76,24 rata-rata kelas dan $61,90 \%$ untuk ketuntasan belajarnya. Sedangkan pada siklus II data tersebut telah meningkat menjadi 82,24 rata-rata kelasnya dan 90,48\% ketuntasan belajarnya. Data pada Siklus II ini sudah menunjukkan keberhasilan pelaksanaan pembelajaran yang melebihi indikator yang dipersyaratkan. Oleh karenanya peneliti berkesimpulan bahwa penerapan model pembelajaran Kooperatif Student Team Achiement Division (STAD) dalam melaksanakan proses pembelajaran mampu meningkatkan prestasi belajar peserta didik.
\end{abstract}

Kata kunci: Prestasi belajar, Model Pembelajaran Kooperatif Student Team Achiement Division (STAD)

\section{ABSTRACT}

The classroom action research carried out has the purpose to improve student learning achievement. Low initial data acquisition for grade IVB students in Semester I Elementary No. 4 Sibanggede 2015/2016 Academic Year makes researchers try to improve the unfavorable processes that have been implemented. Improvement of the learning process is carried out through the application of the Student Team Achiement Division (STAD) Cooperative learning model. This model is expected to solve the problems at hand. After the data was collected through learning achievement test instruments, it was obtained an increase in learning outcomes with initial data that the average class reached 72.57 with a percentage of new learning completeness reaching 33.33\%, in cycle I it increased to 76.24 average class and $61.90 \%$ for completeness of learning. Whereas in the second cycle the data has increased to 82.24 the average class and $90.48 \%$ of the completeness of the study. The data in Cycle II has shown the successful implementation of learning which exceeds the required indicators. Therefore the researchers concluded that the application of the Student Team Achiement Division (STAD) Cooperative learning model in carrying out the learning process was able to improve students' learning achievement.

Keywords: Learning achievement, Cooperative Team Learning Model Achiement Division (STAD) 


\section{PENDAHULUAN}

Kompentensi merupakan perpaduan pengetahuan, keterampilan, nilai dan sikap yang di refleksikan dalam kebiasaan berpikir dan bertindak, (Ashan, 1981) mengemukakan bahwa kompetensi diartikan sebagai pengetahuan, keterampilan, dan kemampuan yang dikuasai oleh seseorang yang telah menjadi bagian dari dirinya, sehingga ia dapat melakukan perilaku-perilaku kognitif, efektif dan psikomotorik dengan sebaik-baiknya.

Berdasarkan hasil pengamatan dan pengalaman bahwa kegiatan belajar mengajar pendidikan PKN sering menjadi kurang menarik bagi siswa karena dianggap sebagai pelajaran yang membosankan yang memerlukan latihan banyak yang monoton, lewat persembahyangan-persembahyangan

sehingga membuat siswa semakin jenuh karena sebagai manusia masih lebih senang dengan kebebasan.

Keadaan di atas membuat peneliti berusaha untuk menemukan dan memilih metode pengajaran yang setepat-tepatnya yang dipandang lebih efektif dari pada metode-metoede lainnya, sehingga kecakapan dan pengetahuan yang diberikan oleh guru benar-benar menjadi milik murid. Salah satu metode yang peneliti gunakan adalah model pembelajaran Kooperatif Student Team Achiement Division(STAD).Tingkat penguasaan siswa terhadap materi pelajaran biasanya dinyatakan dengan nilai. Pada hasil belajar PKN yang sudah diamati sebelumnya sebelum pelaksanaan tindakan menunjukkan rendahnya tingkat penguasaan siswa dalam pembelajaran PKN dengan rata-rata 72,57 dengan ketuntasan belajar 33,33\%.Rata-rata ini jauh di bawah KKM mata pelajaran PKN di SD No. 4 Sibanggede yaitu 78. Hanya 7 orang dari 21 orang siswa di kelas IVB Semester I SD No. 4 Sibanggede Tahun Pelajaran 2015/2016 yang mencapai tingkat panguasaan materi. Untuk meningkatkan penguasaan siswa terhadap materi pelajaran, penulis melaksanakan perbaikan pembelajaran melalui penelitian tindakan kelas.

Berdasarkan uraian di atas peneliti mengangkat masalah tersebut untuk diteliti dalam suatu penelitian tindakan kelas sebagai upaya perbaikan pembelajaran PKN yang diberi judul : "Peningkatan Prestasi Belajar PKN Siswa Kelas IVB Semester I SD No. 4 SibanggedeDengan Menggunakan Model Pembelajaran Kooperatif Student Team Achiement Division (STAD) Tahun Pelajaran 2015/2016"

Penelitian Tindakan Kelas ini mendasarkan rumusan masalah yaitu sebagai berikut :Apakah Penggunaanmodel pembelajaran Kooperatif Students Team Achievement Division (STAD) dapat meningkatkan prestasi belajar PKNsiswa kelas IVB Semester I SD No. 4 Sibanggede Tahun Pelajaran 2015/2016?

Dengan memahami sedikit teori yang bisa ditulis di latar belakang masalah dan alur permasalahan yang telah dipahami, maka tujuan yang dapat disampaikan adalah untuk mengetahui peningkatan prestasibelajar PKNsiswa kelas IVB Semester I SD No. 4 Sibanggede Tahun Pelajaran 2015/2016 setelah diterapkan model pembelajaran Kooperatif Students Team Achievement Division (STAD)dalam pembelajaran.

Penelitian tindakan kelas bermanfaat untuk:Perbaikan dan peningkatan layanan 
profesional guru dalam menangani proses pembelajaran. Terjadinya proses latihan dalam jabatan selama proses penelitian tindakan kelas berlangsung sehingga guru akan lebih banyak mendapatkan pengalaman tentang keterampilan praktek pembelajaran secara reflektif.Menumbuhkan kesadaran akan adanya permasalahan yang dirasakan mengganggu, yang dianggap menghalangi pencapaian tujuan pendidikan sehingga berdampak kurang baik terhadap proses dan atau hasil belajar peserta didik, dan atau implementasi sesuatu program sekolah. Bertolak dari kesadaran mengenai adanya permasalahan tersebut, yang besar kemungkinan masih tergambarkan secara kabur, guru kemudian menetapkan fokus permasalahan secara lebih tajam kalau perlu dengan mengumpulkan tambahan data lapangan secara lebih sistematis dan atau melakukan kajian pustaka yang relevan.

Menurut Purwanto (2000:102) antara lain: (1) faktor yang ada pada diri organisme itu sendiri yang dapat disebut faktor individual, seperti kematangan/pertumbuhan, kecerdasan, latihan, motivasi, dan faktor pribadi, (2) faktor yang ada diluar individu yang disebut faktor sosial., seperti faktor keluarga/keadaan rumah tangga, guru dan cara mengajamya, alat-alat yang dipergunakan dalam belajar-mengajar, lingkungan dan kesempatan yang tersedia dan motivasi sosial. Dalam penelitian ini factor ke 2 yaitu factor yang dari luar seperti guru dan cara mengajarnya yang akan menentukan prestasi belajar siswa. Guru dalam hal ini adalah kemampuan atau kompetensi guru, pendidikan dan lain-lain. Cara mengajarnya itu merupakan factor kebiasaan guru itu atau pembawaan guru itu dalam memberikan pelajaran.

Slamet (2003:54-70) bahwa faktorfaktor yang mempengaruhi belajar banyak jenisnya, tetapi dapat digolongkan menjadi dua golongan saja, yaitu faktor intern dan faktor ekstem. Faktor intern diklasifikasi menjadi tiga faktor yaitu faktor jasmaniah, faktor psikologis dan faktor kelelahan. Faktor jasmaniah antara lain: kesehatan, cacat tubuh. Faktor psikologis antara lain: intelegensi, perhatian, minat, bakat, motif, kematangan, kesiapan. Faktor kelelahan antara lain: kelelahan jasmani dan rohani. Sedangkan faktor ekstern digolongkan menjadi tiga faktor yaitu: faktor keluarga, faktor sekolah, faktor masyarakat. Faktor keluarga antara lain: cara orang tua mendidik, relasi antara keluarga, suasana rumah tangga dan keadaan ekonomi keluarga. Faktor sekolah antara lain: metode mengajar, kurikulum, relasi guru dengan siswa, relasi siswa dengan siswa, disiplin sekolah, pelajaran dan waktu sekolah, standar pelajaran, keadaan gedung, metode belajar dan tugas rumah. Faktor masyarakat antara lain: kegiatan siswa dalam masyarakat, mass media, teman bergaul, bentuk kehidupan masyarakat. Peningkatan prestasi belajar yang peneliti teliti dalam hal ini dipengaruhi oleh factor ekstern yaitu metode mengajar guru.

Sardiman (1988:25) menyatakan prestasi belajar sangat vital dalam dunia pendidikan, mengingat prestasi belajar itu dapat berperan sebagai hasil penilaian dan sebagai alat motivasi.Adapun peran sebagai hasil penilaian dan sebagai alat motivasi diuraikan seperti berikut.

Prestasi belajar tidak akan bisa diketahui tanpa dilakukan penilaian atas hasil aktivitas belajar siswa. Fungsi 
prestasi belajar bukan saja untuk mengetahui sejauhmana kemajuan siswa setelah menyelesaikan suatu aktivitas, tetapi yang lebih penting adalah sebagai alat untuk memotivasi setiap siswa agar lebih giat belajar, baik secara individu maupun kelompok. Dalam pembahasan ini akan dibicarakan mengenai prestasi belajar sebagai hasil penilaian dan pada pembahasan berikutnya akan dibicarakan pula prestasi belajar sebagai alat motivasi. Prestasi belajar sebagai hasil penilaian sudah dipahami.Namun demikian untuk mendapatkan pemahaman, perlu juga diketahui, bahwa penilaian adalah sebagai aktivitas dalam menentukan rendahnya prestasi belajar itu sendiri.

Menurut Slavin (1995:5) pada awalnya teori itu mendapat soal yangdikerjakan oleh masing-masing anggota tim, pada saat awal tersebut masing-masinganggota tim tidak saling membantu, artinya mereka pada awalnya bekerja sendiri-sendiri. Apabila salah satu anggota tim menemui kesulitan diharapkan anggota timyang lain dapat menolongnya.Dalam pelaksanaannya guru perlu mencatat tim yang sukses memberikanjawaban terhadap pertanyaan/kuis yang diberikan dan tim yang terbaik akanmendapat hadiah. Anggota tim mesti meyakinkan temannya bahwa belajar itu adalahpenting, bernilai dan menyenangkan. Mereka bisa bekerja berpasangan dan salingmembandingkan jawaban-jawaban, berdiskusi, saling tolong dengan penuhpengertian. Mereka bisa membahas cara-cara untuk mengatasi masalah atau salingbertanya tentang apa yang mereka pelajari, membahas kekurangan-kekurangan yangada pada diri mereka atau juga kelebihan-kelebihan yang ada dalam upaya agarmereka mampu menjawab apa yang ditanyakan.

Meskipun siswa bekerja bersama, tetapi pada saat guru melontarkanpertanyaan, masing-masing siswa tidak saling membantu, pada saatsaat yangdemikian akan terlihat murid yang mampu dan yang akan menjadi bintang tim untuksementara. Model ini merupakan model dari kooperatif yang paling sederhana, inibagus bagi para guru yang baru saja melangkah atau mulai mengajar denganpengajaran model bertim.

Slavin, 1995 (dalam Ni Luh Rasmini, 2010: 24-26) menyatakan bawha pembelajaran kooperatif tipe Students Team Achievement Division (STAD) terdiri dari lima komponen utama yang perlu diperhatikan yaitu tahap penyajian kelas (class presentation), belajar dalam kelompok (team), tes/kuis (quizzes), skor kemajuan individu (individual improvment scores) dan penghargaan kelompok (team recognation). Dan ciri-ciri pembelajaran kooperatif Students Team Achievement Division (STAD) adalah: 1) siswa belajar dalam kelompok-kelompok kecil, 2) memperhatikan skor awal, 3) terdapat kuis/tes, 4) skor kemajuan individual, 5) penghargaan kelompok (caranya rata-rata kelompok dihitung dari skor kemajuan individual masing-masing anggota, dijumlah dan dibagi dengan jumlah kelompok, baru dikasi hadiah).

Uraian materi pembelajaran yang telah disampaikan menuntun peneliti merumuskan hipotesis tindakan seperti berikut : Apabila PenggunaanModel pembelajaran Kooperatif Students Team Achievement Division (STAD) Digunakan Dengan Baik Sesuai Teori Para Ahli MakaDapat Meningkatkan Prestasi BelajarPKN Siswa KelasIVB Semester I 
SD No. 4 Sibanggede Tahun Pelajaran 2015/2016.

SD No. 4 Sibanggede dijadikan lokasi penelitian. Semua pihak di sekolah tempat penelitian ini dilaksanakan telah giat mewujudkan lingkungan yang baik sehingga sekolah ini aman, nyaman dan asri.

Pentingnya sebuah rancangan penelitian adalah untuk menuntun agar peneliti tersebut terarah, rancangan penelitian ini diambil dari seorang ahli yang bernama Mc. Kernan.

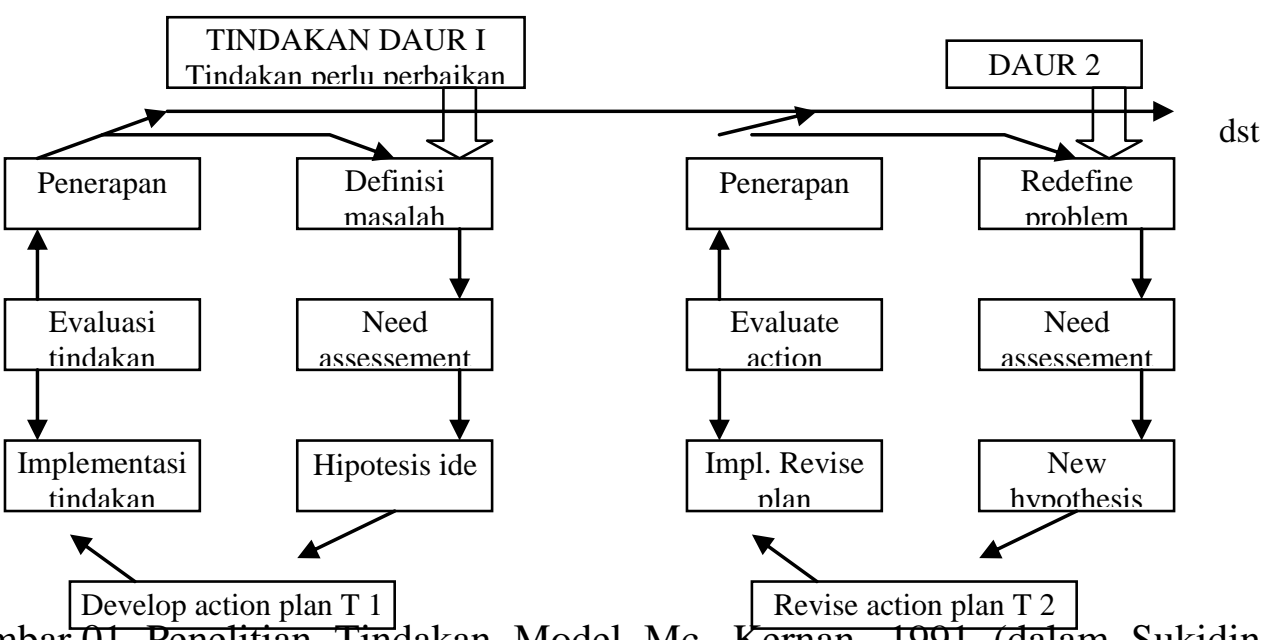

Gambar 01. Penelitian Tindakan Model Mc. Kernan, 1991 (dalam Sukidin, Basrowi, Suranto, 2002:54)

Subjek pada penelitian ini adalah siswa kelas IVB Semester I SD No. 4 Sibanggede Tahun Pelajaran 2015/2016.Penelitian Tindakan Kelas ini dilakukan mulai dari bulan Juli sampai November tahun 2015.Cara pengumpulan data dalam penelitian ini dilakukan dengan tes prestasi belajar.Sehubungan dengan data yang diperoleh adalah angka maka analisis deskriptif yang peneliti gunakan adalah data kuantitatif.Untuk data kuantitatif dianalisis dengan mencari mean, median, modus, membuat interval kelas dan melakukan penyajian dalam bentuk tabel dan grafik.Dengan rata-rata nilai siswa pada siklus I mencapai 78 dengan ketuntasan $80 \%$ dan pada siklus II mencapai 78 dengan ketuntasan $85 \%$, maka penelitian ini sudah dianggap berhasil.

\section{HASIL PENELITIAN DAN PEMBAHASAN}

Hasil Penelitian

\section{Deskripsi Awal}

Pelaksanaan yang dilakukan dalam kegiatan awal diperoleh data yaitu, ada 7 orang siswa $(33,33 \%)$ dari 21 orang di kelas IVB Semester I SD No. 4 Sibanggede Tahun Pelajaran 2015/2016 memperoleh nilai memenuhi KKM dan ada cukup banyak siswa yaitu 14 orang siswa di kelas ini memperoleh nilai di bawah KKM. Ketidakberhasilan tersebut banyak dipengaruhi oleh faktor ketidaksiapan guru dalam membuat perencanaan, profesionalisme guru dalam melaksanakan pembelajaran dan kesiapan guru dalam mempelajari keilmuan-keilmuan yang mesti ditetapkan dalam melaksanakan proses 
pembelajaran. Kelebihan yang telah diperbuat adalah peneliti sebagai guru di SD No. 4 Sibanggedetelah berupaya semaksimal mungkin agar peningkatan mutu pendidikan di sekolah ini dapat berjalan sesuai harapan.

\section{Deskripsi Siklus I}

a. Perencanaan I

Yang telah dilakukan dalam perencanaan Siklus I ini adalah banyak hal yaitu : Menyusun jadwal untuk pelaksanaan.Menyusun rencana kegiatan.
1) Menyusun
format penilaian.Membuat bahan-bahan pendukung pembelajaran lainnya.Merancang skenario pembelajaran model pembelajaran Kooperatif Student Achiement Division (STAD).

\section{b. Pelaksanaan I}

Pelaksanaan penelitian pada siklus I menggunakan skenario pembelajaran model pembelajaran kooperatif STAD.

\section{c. Observasi I}

Dari hasil observasi berupa tabel nilai diatas dapat disampaikan hasil data sebagai berikut: setelah dilakukan kegiatan penelitian dengan menggunakan model pembelajaran kooperatif STAD pada siklus I rata-rata nilai siswa yang baru dicapai adalah 76,24.Dari 21 orang siswa ada 13 orang siswa sudah dikatakan tuntas dan 8 orang siswa yang belum tuntas dengan prosentase ketuntasan belajar $61,90 \%$.

\section{d. Refleksi I}

1) Analisis
Dari analisis kualitatif sudah disampaikan secara singkat, selanjutnya diberikan analisis kuantitatifnya menggunakan data yang diperoleh adalah dalam bentuk angka sebagai berikut :

a) Rata-rata (mean) dihitung dengan: $\frac{\text { Jumla hilai }}{\text { Jumla } h \text { siswa }}=$ $\frac{1601}{21}=76,24$

b) Median (titik tengahnya) dicari dengan mengurut data/nilai siswa dari yang terkecil sampai terbesar. Setelah diurut apabila jumlah data ganjil maka mediannya adalah data yang ditengah. Kalau jumlahnya genap maka dua data yang di tengah dijumlahkan dibagi 2 (dua). Untuk median yang diperoleh dari data siklus I dengan menggunakan cara tersebut adalah78.

c) Modus (angka yang paling banyak/paling sering muncul) setelah diasccending/diurut. Angka tersebut adalah78.

d) Untuk persiapan penyajian dalam bentuk grafik maka hal-hal berikut dihitung terlebih dahulu.

1. Banyak kelas $(\mathrm{K})=1+$ $3,3 \times \log (\mathrm{N})=1+$ $4,35=5,35 \rightarrow 6=1+$ $3,3 \times \log 21=1+(3,3$ $\mathrm{x} 1,32$ )

2. Rentang kelas (r) = skor maksimum - skor minimum $=83-68=15$ 
3. Panjang kelas interval (i) $=$ $\frac{r}{K}=\frac{15}{6}=2,5 \rightarrow 3$

4. Data Interval Kelas

Tabel 01. Data Interval Kelas Siklus I

\begin{tabular}{ccccc}
\hline $\begin{array}{c}\text { No } \\
\text { ut }\end{array}$ & $\begin{array}{c}\text { Inter } \\
\text { val }\end{array}$ & $\begin{array}{c}\text { NilaiTen } \\
\text { gah }\end{array}$ & $\begin{array}{c}\text { FrekuensiAb } \\
\text { solut }\end{array}$ & $\begin{array}{c}\text { FrekuensiR } \\
\text { elatif }\end{array}$ \\
\hline 1 & $\begin{array}{c}73- \\
75\end{array}$ & 69.0 & 4 & 19.05 \\
\hline 2 & $\begin{array}{c}76- \\
78\end{array}$ & 72.0 & 2 & 9.52 \\
\hline 3 & $\begin{array}{c}79- \\
81\end{array}$ & 75.0 & 2 & 9.52 \\
\hline 4 & $\begin{array}{c}72- \\
84\end{array}$ & 78.0 & 8 & 38.10 \\
\hline 5 & $\begin{array}{c}75- \\
87\end{array}$ & 81.0 & 3 & 14.29 \\
\hline 6 & $\begin{array}{c}88- \\
90\end{array}$ & 84.0 & 2 & 9.52 \\
\hline
\end{tabular}

5. Penyajian dalam bentuk histogram

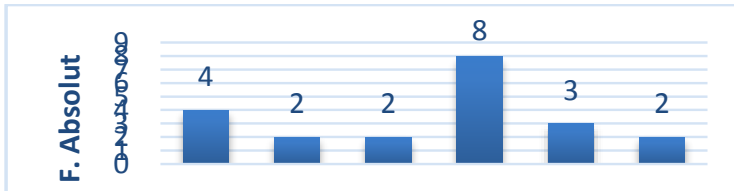

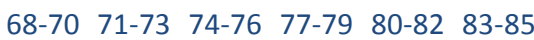

NILAI

Gambar

02.

HistogramPrestasiBelajarPKN

SiswaKelas IVB Semester I SD No. 4 Sibanggede Tahun Pelajaran 2015/2016 Siklus I

\section{2) Sintesis}

Perkembangan mutu belajar siswa pada Siklus I ini adalah dari 21 orangsiswa yang diteliti ternyata hasilnya belum sesuai dengan harapan. Dari perkembangan tersebut diketahui adanya kekurangan yaitu pada penilaian hasil belajar mereka, hanya 13orang siswa yang sudah mampu mencapai KKM dan 8 orang siswa yang belum mencapai KKM. Hasil tersebut menunjukan bahwa kemampuan siswa masih di bawah tuntutan indikator keberhasilan yaitu minimal $80 \%$ siswa mampu mencapai nilai KKM.

3) Penilaian Siklus I

Kekurangan-kekurangan serta kelebihan-kelebihan yang ada adalah Belum semua siswa aktif dalam mengikuti proses pembelajaran. Dalam satu kelompok sebagian siswa hanya menonton temannya melakukan kegiatan. Kelebihan yang ada adalah:Peneliti telah menerapkan model pembelajaran Kooperatif Student Achiement Division (STAD) dengan sebaik-baiknya.

Semua kekurangan yang telah disampaikan itu akan dibenahi pada Siklus ke II.

\section{Deskripsi Siklus II}

a. Perencanaan II

Semua kelemahan yang sudah dipaparkan pada siklus I merupakan acuan untuk membuat perencanaan pada siklus II ini. Adapun perencanaan yang dilakukan pada siklus II yaitu Menyusun jadwal untuk pelaksanaan.Menyusun rencana kegiatan. Menyusun format penilaian.Membuat bahan-bahan pendukung pembelajaran lainnya.Merancang skenario pembelajaran model pembelajaran Kooperatif Student Achiement Division (STAD).

\section{b. Pelaksanaan II}

Pelaksanaan penelitian pada siklus II menggunakan skenario pembelajaran model pembelajaran kooperatif STAD.

\section{c. Pengamatan/Observasi II}

Dari hasil observasi berupa tabel nilai diatas dapat disampaikan hasil 
data sebagai berikut : setelah dilakukan kegiatan penelitian dengan menggunakan model pembelajaran kooperatif STADpada siklus II rata-rata nilai siswa adalah 82,24. Dari 21 orang siswa sudah ada 19orang siswa sudah dikatakan tuntas dan hanya 2 orang siswa yang belum tuntas dengan prosentase ketuntasan belajar $90,48 \%$.

\section{d. Refleksi II}

\section{1) Analisis}

Hasil yang diperoleh dengan pemberian tes prestasi belajar dapat dijelaskan: dari 21orang siswa yang diteliti sudah semua siswa mendapat nilai rata-rata KKM. Interpretasi yang muncul dari data tersebut adalah bahwa mereka sudah sangat mampu melakukan apa yang disuruh. Analisis ini menunjukkan bahwa lebih dari setengah siswa sudah mampu meningkatkan prestasi belajarnya. Dengan semua hasil tersebut dapat dideskripsikan bahwa indikator keberhasilan penelitian yang diharapkan sudah terpenuhi. Dari analisis kualitatif sudah disampaikan secara singkat, selanjutnya diberikan analisis kuantitatifnya menggunakan data yang diperoleh adalah dalam bentuk angka sebagai berikut :

a) Rata-rata (mean) dihitung dengan: $\frac{\text { Jumla } h \text { nilai }}{\text { Jumla } h \text { siswa }}=$ $\frac{1727}{21}=82,24$

b) Median siklus II adalah82.

c) Modus (angka yang paling banyak/paling sering muncul) setelah diasccending/diurut. Angka tersebut adalah81.

d) Untuk persiapan penyajian dalam bentuk grafik maka hal-hal berikut dihitung terlebih dahulu.

1. Banyak kelas $(\mathrm{K})=1+$ $3,3 \times \mathrm{L}=1+3,3 \times \log$ $21=1+3,=1+4,35=$ $5,35 \rightarrow 6$

2. Rentang kelas (r) = skor maksimum skor minim $=88-73=15$

3. Panjang kelasinterval (i) $=\frac{r}{K}=\frac{15}{6}=2,5 \rightarrow 3$

4. Data Interval Kelas Tabel 02. Data Interval Kelas Siklus II

\begin{tabular}{|c|c|c|c|c|}
\hline $\begin{array}{c}\text { No } \\
\text { Urut }\end{array}$ & Interval & NilaiTengah & FrekuensiAbsolut & FrekuensiRelatif \\
\hline 1 & $73-75$ & 74.0 & 1 & 4.76 \\
\hline 2 & $76-78$ & 77.0 & 2 & 9.52 \\
\hline 3 & $79-81$ & 80.0 & 5 & 23.81 \\
\hline 4 & $72-84$ & 83.0 & 7 & 33.33 \\
\hline 5 & $75-87$ & 86.0 & 3 & 14.29 \\
\hline 6 & $88-90$ & 89.0 & 3 & 14.29 \\
\hline \multicolumn{3}{|c|}{ Total } & 21 & 100.00 \\
\hline
\end{tabular}

5. Penyajian dalam bentuk Histogram

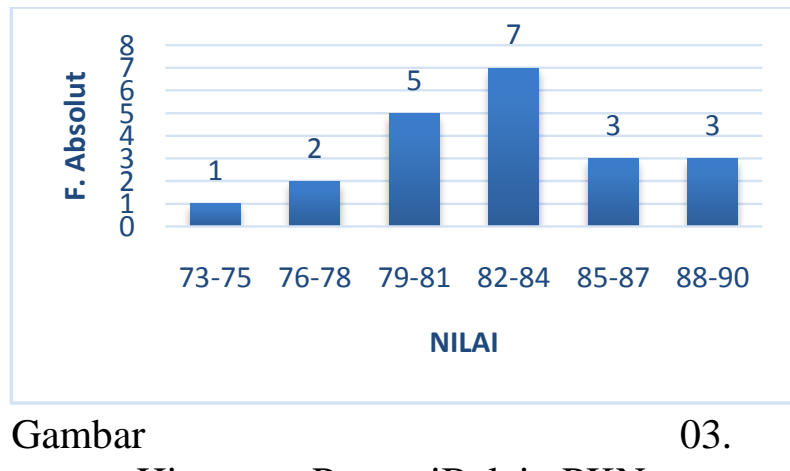

HistogramPrestasiBelajarPKN

SiswaKelas IVB Semester I SD No. 4 Sibanggede Tahun Pelajaran 2015/2016 Siklus II

2) Sintesis

Sintesis yang dapat disampaikan adalah pada siklus II, dari 21 orangsiswa yang 
diteliti ternyata hasilnya sudah sesuai dengan harapan. Dari perkembangan tersebut diketahui hampir semua siswa sudah mampu untuk melakukan apa yang disuruh dengan baik. Pada siklus II ini peserta didik sudah giat dan mau belajar untuk meningkatkan prestasinya. Dari semua data yang sudah diperoleh tersebut dapat diberikan sintesis bahwa sebagian besar siswa sudah mampu meningkatkan prestasi mereka, hal tersebut berarti indikator yang diharapkan dicapai oleh siswa-siswiSD No. 4 Sibanggede sudah dapat dicapai.

3) Penilaian Siklus II

Penilaian yang dapat disampaikan terhadap seluruh kegiatan tindakan Siklus II ini bahwa indikator yang dituntut dalam pembelajaran dengan menggunakan model pembelajaran Kooperatif Student Team Achievement Division(STAD) sudah berhasil diupayakan. Semua kekurangankekurangan yang ada sebelumnya sudah diperbaiki pada siklus ini, semua indikator yang dituntut untuk diselesaikan tidak ada lagi yang tertinggal. Hasil yang diperoleh pada Siklus II ini menunjukkan bahwa penelitian ini tidak perlu dilanjutkan lagi ke siklus berikutnya. Tuntutan indikator keberhasilan penelitian yang dicanangkan $85 \%$ siswa atau lebih dapat mencapai peningkatan, dan ternyata sudah $90,48 \%$ siswa sudah berhasil.

\section{Pembahasan}

Data awal yang diperoleh dengan rata-rata72,57menunjukkan bahwa kemampuan siswa dalam mata pelajaranPKNmasih sangat rendah mengingat kriteria ketuntasan belajar siswa untuk mata pelajaran ini di SD No. 4 Sibanggede adalah 78. Dengan nilai yang sangat rendah seperti itu maka peneliti mengupayakan untuk dapat meningkatkan prestasi belajar siswa menggunakan model pembelajaran Kooperatif Student Team Achievement Division (STAD). Akhirnya dengan penerapan model pembelajaran Kooperatif Student Team Achievement Division (STAD) yang benar sesuai teori yang ada, peningkatan rata-rata prestasi belajar siswa pada siklus I dapat diupayakan dan mencapai rata-rata76,24\%. Namun rata-rata tersebut belum maksimal karena hanya13 orang siswa memperoleh nilai memenuhi KKM sedangkan yang lainnya belum mencapai KKM. Sedangkan prosentase ketuntasan belajar mereka baru mencapai61,90\%. Hal tersebut terjadi akibat penggunaan model pembelajaran Kooperatif Student Team Achievement Division (STAD) belum maksimal dapat dilakukan disebabkan penerapan model tersebut baru dicobakan sehingga guru masih belum mampu melaksanakannya sesua alur teori yang benar.

Pada siklus ke II perbaikan prestasi belajar siswa diupayakan lebih maksimal dengan peneliti membuat perencanaan yang lebih baik, menggunakan alur dan teori dari model pembelajaran Kooperatif Student Team Achievement Division (STAD) dengan benar dan lebih maksimal. Peneliti giat memotivasi siswa agar giat 
belajar, memberi arahan-arahan, menuntun mereka untuk mampu menguasai materi pelajaran pada mata pelajaranPKN lebih optimal. Akhirnya dengan semua upaya tersebut peneliti mampu meningkatkan prestasi belajar siswa pada siklus II menjadi rata-rata82,24 dengan ketuntasan belajar (90,48\%). Upaya-upaya yang maksimal tersebut menuntun pada suatu keberhasilan bahwa model pembelajaran Kooperatif Student Team Achievement Division (STAD) mampu meningkatkan prestasi belajar siswa.

\section{PENUTUP}

\section{Simpulan}

Dari hasil refleksiyang telah disampaikan di Bab IV dan dengan melihat semua data yang telah dipaparkan, dapat disampaikan bahwa pencapaian tujuan penelitian di atas dapat dibuktikan dengan argumentasi sebagai berikut : Dari data awal ada 14 orang siswa mendapat nilai dibawah KKM dan pada siklus I menurun menjadi 8 orang siswa dan siklus II hanya 2 orang siswa yang mendapat nilai di bawah KKM.Nilai rata-rata awal 72,57 naik menjadi 76,24 pada siklus I dan pada siklus II naik menjadi82,24. Dari data awal siswa yang tuntas hanya 7 orang sedangkan pada siklus I menjadi lebih banyak yaitu 13 orang siswa dan pada siklus II sudah ada 19 orang siswa tuntas.Dari data awal ketuntasan belajar siswa hanya mencapai $33,33 \%$, kemudian meningkat menjadi $61,90 \%$ pada siklus I, dan pada siklus II menjadi 90,48\%.

Paparan di atas membuktikan bahwa model pembelajaran Kooperatif Student Team Achievement Division (STAD) dapat memberi jawaban sesuai tujuan penelitian ini. Semua ini dapat dicapai karena model pembelajaran
Kooperatif Student Team Achievement Division (STAD) sangat efektif diterapkan dalam proses pembelajaran yang mengakibatkan siswa aktif, antusias dan dapat memahami materi yang diajarkan sehingga prestasi belajar siswa menjadi meningkat.

\section{Saran}

Saran yang disampaikan oleh peneliti pada Penelitian Tindakan Kelas ini adalah sebagai berikut :Bagi guru kelas, apabila mau melaksanakan proses pembelajaran penggunaan model yang telah diterapkan ini semestinya menjadi pilihan dari beberapa model yang ada mengingat model ini telah terbukti dapat meningkatkan prestasi belajar siswa.Bagi peneliti lain, walaupun penelitian ini sudah dapat membuktikan efek utama dari model pembelajaran Kooperatif Student Team Achievement Division (STAD) dalam meningkatkan prestasi belajar, sudah pasti dalam penelitian ini masih ada hal-hal yang belum sempurna dilakukan, oleh karenanya disarankan kepada peneliti lain yang berminat meneliti topik yang sama untuk meneliti bagian-bagian yang tidak sempat diteliti.Bagi pengembang pendidikan, selanjutnya untuk adanya penguatan-penguatan, diharapkan bagi peneliti lain untuk melakukan penelitian lanjutan guna menyempurnakan data hasil penelitian ini.

\section{DAFTAR PUSTAKA}

Arikunto, S; Suhardjono; Supardi. (2006). Penelitian Tindakan Kelas. Jakarta: PT Bumi Aksara.

Purwanto, N. (2000). Psikologi Pendidikan. Bandung: RoSMAakarya. Sardiman, A.M. (1988). Interaksi dan Motivasi Belajar-Mengajar Pedoman bagi Guru dan Calon Guru.Jakarta: Rajawali Pers. 
Slameto. (2003). Belajar dan FaktorFaktor yang Mempengaruhinya. Jakarta: Rineka Cipta.

Slavin, R. E. (1995). Cooperative Learning : Theory, Research, and Practice.Boston: Allyn and Bacon.
Sukidin, Basrowi, Suranto. (2002. Menajemen Penelitian Tindakan Kelas. Penerbti: Insan Cendekia ISBN: $979 \quad 9048 \quad 33 \quad 4$. 